Nloman 2020, 38(1), 15-20

Revista de Psicologia, Ciències de l'Eduació i de l'Esport

ISSN: $1138-3194$

CFacultat de Psicologia, Ciències de l'Educació i de l'Esport Blanquerna

Universitat Ramon Llull

(c) (1) \$(

BY NG SA

\title{
Generation Lockdown: Exploring possible predictors of technology phobia during the Coronavirus self-isolation period
}

\author{
Neil Daruwala \\ Derby University (UK)
}

Received: 2020-4-23

Accepted: 2020-4-29

Generation Lockdown: Exploring possible predictors of technology phobia during the Coronavirus self-isolation period

\begin{abstract}
Summary. The purpose of this article is to present possible psychological consequences of using ICT, especially online communication applications, during the Coronavirus lockdown. With humans already testing their mental fortitude due to the enforced isolation period, the paper proposes that predictors of technology phobia such as computer anxiety may also arise. The root causes of technophobia are centred around computer dependency, data surveillance, information overload, poor user experience and personality type. Furthermore, scenarios such as a complete internet shutdown, the development of social distancing apps and the introduction of $5 G$ are also dissected within the article. Finally, the reader is presented with ideas on feasible solutions and coping mechanisms in dealing with technology-related stress. It seems evident that there exists a need for academia and governmental entities to work in- tandem in order to implement common-sense legislation.
\end{abstract}

Keywords: technostress; technophobia; coronavirus; society

Generación confinamiento: exploración de posibles predictores de fobia tecnológica durante el período de autoaislamiento de coronavirus

Resumen. El propósito de este artículo es presentar las posibles consecuencias psicológicas del uso de las TIC, especialmente las aplicaciones de comunicación en línea, durante el confinamiento debido al coronavirus. Las personas ya están poniendo a prueba su fortaleza mental debido al período de aislamiento forzado, este artículo propone que también puedan surgir predictores de fobia tecnológica como la "ansiedad por computadora" (computer anxiety). Las causas fundamentales de la tecnofobia se centran en la dependencia de la computadora, la vigilancia de datos, la sobrecarga de información, la mala experiencia del usuario y el tipo de personalidad. Además, en el artículo también se analizan escenarios como el cierre completo de Internet, el desarrollo de aplicaciones de distanciamiento social y la introducción de 5G. Finalmente, se presentan ideas para soluciones viables y mecanismos de afrontamiento para lidiar con el estrés relacionado con la tecnología. Parece evidente que existe la necesidad de que la academia y las entidades gubernamentales trabajen conjuntamente para implementar la legislación de sentido común.

Palabras clave: tecnostress; tecnofobia; coronavirus; sociedad 


\section{Introduction}

In early January 2020, distressing images of Chinese civilians being forced to self-isolate and dragged, kicking and screaming to hospitals and clinics, were beamed around the globe. Some in the West thought the governmental overreach to the flu-like virus was an archetypical communist act from the authoritative Chinese government. The Chinese are just using the virus as an excuse to exercise their technology-based credit system (Zhou \& Xiao, 2020) we exclaimed. Two months later and all of Europe and half the world is in lockdown. People with an affinity with technology, known as technophiles (Dastjerdi, Kaplan, Silva, Nielsen, \& Pereira, 2019), could view information and communication technology (ICT) as a saving grace, as it is, for the moment, humans' primary source for communication. However, ICT could also be used to ensure we abide by emergency governmental legislation, and concepts such as social distancing and human surveillance are now being enforced on the world's population.

The irregular situation we find ourselves in could cause an upsurge of negative predictors of technophobia even from people who previously embraced technology. Technophiles, for example, are characterised as having enthusiasm for technologically-based activities and embrace social change expressed in positive futuristic outcomes (Osiceanu, 2015). Technophiles are also highly dependent on technology (Martínez-Córcoles, Teichmann, \& Murdvee, 2017) as we all are due to the lockdown. Nevertheless, this over-reliance on the digital world may lead to physical and psychological strain, known as technostress (Tarafdar, Tu, B.S. Ragu-Nathan \& Ragu-Nathan, 2007; Lee, Son, \& Kim, 2016).

Therefore, the purpose of this article is to make some considerations on the possible manifestation of stress due to ICT usage during the coronavirus lockdown. Focussing on communication ICTs, the paper proposes to promote research hypotheses related to the effects of slow bandwidths, poor quality user experience and the solutions provided by big technology companies such as $5 \mathrm{G}$. Furthermore, possible factors that encapsulate technophobia will be highlighted. Such factors include computer anxiety (Chesley, 2014), negative attitudes to computers, style of thought (Brosnan, 2002), exhaustion (Day, Paquet, Scott, \& Hambley, 2012) and individual factors which influence the incidence of other specific phobias such as cultural, environmental and genetic factors. (Maj, Akiskal, LopezIbor, \& Okasha, 2004).

Due to the pandemic sweeping across the world, face to face interaction, which provides a more fulfilling experience than virtual relations (Pénard \& Poussing, 2010), has been limited for the foreseeable future. Therefore, social distancing seems to be the perfect excuse for humans to uptake their technology usage and connect even more with their friends and family. Curiously, a study that used Wuhan as one of its test cities found online interpersonal communication did not advance peoples quality of life and in fact, could be detrimental to one's wellbeing. (Lee, Leung, Lo, Xiong, \& Wu, 2010). With low quality of life linked to phobias (Barrera \& Norton, 2009) there is a possibility that people may develop a rejection of technology especially during these uncertain times of self-isolation, which in itself causes psychology distress (Hawkley \& Capitanio, 2015). However, the Wuhan study could have explored personality types as research indicates extroverts positively adapt to the online environment more than introverts and thus are less likely to show symptoms of technophobia. (Valkenburg \& Peter, 2005; Lee, 2009)

There exists a wealth of studies that highlight the usefulness of technology in maintaining contact with friends and family (Fox \& Moreland, 2015; Wellman et al., 2001; Boase \& Wellman, 2006). However, caution is advised as most positive outcomes are generally due to participants being online social butterflies with a large number of online contacts and a favourable social currency. Conflicting outcomes suggest that people who do not possess' online clout or a myriad of online networks will feel negative emotions, anxiety, paranoia and possibly technophobia (Scissors, Burke, \& Wengrovitz, 2016). Lee (2009) illustrates the point in his study by affirming the rich get richer hypothesis and the poor, well they remain, socially speaking, poor.

Moreover, successful online users with large networks of friends and family can experience heightened levels of anxiety. Twitter influencer Essena O'Neill terminated her account implying that online success induced dependency and stress, when she stated, "I remember I obsessively checked the like count for a full week since uploading it" (Hunt, 2015, November 03). Her evidence is not anecdotal, as she oversaw the creation of a walkaway movement which aimed to lessen time online (Krasnova, Spiekermann, Koroleva, \& Hildebrand, 2010; Gartner 2011). As a result, while positive evaluations regarding communication via the internet are evident major concerns over ICTs coexist (Lee, 2009). Furthermore, it is possible during extraordinary circumstances such as a worldwide lockdown overdependence to ICT can lead to computer stress or anxiety for all personality types, extroverts included.

The usage of Zoom, Whatsapp and other social media applications have increased substantially. On March 23, 2020, when it was apparent that social distancing was going to be imposed, Zoom was downloaded over 2 million times. Nevertheless, with our civil liberties already being encroached upon, (Haddon, Hogarth, Nice, \& Marshall, 2020) do we need to be slightly paranoid about how our data is currently being used? Can these technologies cause anxiety and eventually cause rejection and even technophobia? The case of dog walkers being followed by police drones ( $\mathrm{O}^{\prime} \mathrm{Neill}$, 2020) springs to mind and highlights how fragile our civil rights are. Indeed, the police overreach saw a backlash and calls for the perceived Orwellian surveillance tactics to cease (Holden, 2020). Once tech com- 
panies like Google and Landing AI release their "transparent" social distance apps using machine learning to keep "communities safe" (Hao, 2020), can the authorities be trusted to use the devices in a measured way or will people be recorded and fined for not keeping the reglementary six feet distance from each other? Only time will tell but as the old adage goes, power tends to corrupt, and absolute power corrupts absolutely (Acton, Figgis, \& Laurence, 1906).

Moreover, in self-reporting studies, people do state that privacy is an important issue. However, yet as many tech companies use the magician's sleight of hand to exploit our data, the masses up till now, have accepted the Faustian bargain of more online fun for the exchange of our privacy. However, last year Zoom was taken to task by the tech industry after it became common knowledge that the videotelephony and online chat platform contained a digital virus and had a Remote Code Execution (RCE) vulnerability issue which permitted any website to forcibly join a user during a Zoom call, without the user's permission (Leitschuh, 2019). Now we know why the FBI's ex-director, James Comey said he places a piece of tape over his computer's camera because he saw somebody smarter than him do the same thing, possibly referring to Mark Zuckerberg who also covers up his computer camera (Kaste, 2016). Thus, it is likely that, although we can solely communicate with friends and family online for the short term, it is a preoccupation that by proxy we will be providing even more residual data to the technocrats in Silicon Valley.

Most people would agree that having technology during this pandemic is preferable to having no possibility of contact with others. Indeed, if the internet goes down due to saturation and overuse, the consequences could be dire (Cuthbertson, 2020). However, there exists a plethora of information regarding the pandemic being circulated between friends and family, which could lead to an infodemic which, in turn, could confuse and cause more anxiety. Seeing videos and images of people in a hospital bed struggling to breath will only negatively affect our stress levels, which can weaken our immune system and as we know, our immune system must remain healthy especially during the lockdown (Munshi et al., 2020). Unfortunately, what information to digest is problematic as even The World Health Organization, who coined the word "infodemic" have tweeted false information by initially stating the virus was not contagious (Givas, 2020). Daily reports of the virus death count or false hope of a new vaccine only add to our anxiety and could be the catalyst for an increase in technophobia instances.

As bandwidths and wifi usage are optimal due to the pandemic, some are worried that the internet speeds may lag causing poor sound and image quality while communicating with friends and family and thus creating unsatisfactory online communication experiences. The major Tech companies have championed $5 \mathrm{G}$ as the solution to slow bandwidth speed and stated it works up to 10 times faster than $4 \mathrm{G}$. Nevertheless,
$5 \mathrm{G}$ is gaining some opposition from the medical, environmental and technology sectors (Kelley, 2019). One issue is the possible harm excessive levels of radiation used for $5 \mathrm{G}$ output known as, radiofrequency electromagnetic radiation (RF EMR), can exact on all living species (Russell, 2018). The other problem is that $5 \mathrm{G}$ uses millimetre waves (Bogale, Wang, \& Le, 2017), which cannot travel through solid objects and has a small frequency range. The results could see environmental destruction (urban deforestation) in order to place the millions of units needed for extensive and penetrative $5 \mathrm{G}$ global coverage. Even though conclusive evidence is still unavailable, $5 \mathrm{G}$ is an integral part of the internet of things which will eventually create our smart homes and smart cities which in turn, will make it harder to opt-out of the technology-driven world.

\section{Conclusion}

Phobia development theory is inconclusive; however, etiological models propose the disorder manifests itself via situations, either innate or learnt, that trigger our fear systems (Fyer, 1998). If all our fears regarding constant technology consumption, people's desire for faster connectivity, data and human surveillance, 5G heath risks and smart cities come true, then technophobia will not be an irrational fear but a real concern with dystopian consequences. Research is needed to develop effective strategies on how to deal with stress and phobia associated with ICT. Indeed, interventions to promote coping mechanisms against technostress (Cuervo-Carabel, Meneghel, Orviz-Martínez, \& ArceGarcía, 2020) could provide valuable solutions to an ever-increasing problem. However, researchers, academia and governmental bodies need to work together in order to translate thorough empirically based research into legislation.

\section{References}

Acton, J. E. E. D., Figgis, J. N., \& Laurence, R. V. (1906). Lectures on modern History. London.

Baltaci, O. (2019). The Predictive Relationships between the Social Media Addiction and Social Anxiety, Loneliness, and Happiness. International Journal of Progressive Education, 15(4), 73-82. doi: 10.29329/ ijpe.2019.203.6

Barrera, T. L., \& Norton, P. J. (2009). Quality of life impairment in generalized anxiety disorder, social phobia, and panic disorder. Journal of anxiety disorders, 23(8), 1086-1090. https://doi.org/10.1016/j. janxdis.2009.07.011

Boase, J., \& Wellman, B. (2006). Personal Relationships: On and Off the Internet. In A. L. Vangelisti \& D. Perlman (Eds.), The Cambridge handbook of personal relationships (p. 709-723). Cambridge University Press.

Bogale, T., Wang, X., \& Le, L. (2017). mmWave communication enabling techniques for $5 \mathrm{G}$ wireless systems. MmWave Massive MIMO, 195-225. doi: 10.1016/b978-0-12-804418-6.00009-1 
Brosnan, M. (2002). Technophobia: The psychological impact of information technology. London: Routledge.

Chesley, N. (2014). Information and communication technology use, work intensification and employee strain and distress. Work, employment and society, 28(4), 589-610. doi: https://doi.org/10.1177/ 0950017013500112

Cuervo-Carabel, T., Meneghel, I., Orviz-Martínez, N., $\&$ Arce-García, S. (2020, in press.). Nuevos retos asociados a la tecnificación laboral: el tecnoestrés y su gestión a través de la Psicología Organizacional Positiva (The New Challenges of the Technification of Work: Managing "Technostress" Through Positive Organizational Psychology). Aloma: Revista de Psicologia, Ciències de l’Educació i de l'Esport, 38(1).

Cuthbertson, A. (2020, March 23). AT\&T boss says internet seeing 'some signs of stress' as people work from home across US. Retrieved from https://www.independent.co.uk/life-style/gadgets-and-tech/news/coronavirus-internet-broadband-down-att-a9417571.html

Dastjerdi, A. M., Kaplan, S., Silva, J. D. A. E., Nielsen, O. A., \& Pereira, F. C. (2019). Use intention of mobility-management travel apps: The role of users goals, technophile attitude and community trust. Transportation Research Part A: Policy and Practice, 126, 114-135. doi: 10.1016/j.tra.2019.06.001

Day, A., Paquet, S., Scott, N. \& Hambley, L. (2012). Perceived information and communication technology (ICT) demands on employee outcomes: The moderating effect of organizational ICT support. Journal of Occupational Health Psychology, 17(4), 473491. doi: http://dx.doi.org/10.1037/a0029837

Fox, J., \& Moreland, J. J. (2015). The dark side of social networking sites: An exploration of the relational and psychological stressors associated with Facebook use and affordances. Computers in Human Behavior, $45,168-176$.

Fyer, A. J. (1998). Current approaches to etiology and pathophysiology of specific phobia. Biological Psychiatry, 44(12), 1295-1304. doi: 10.1016/s0006-3223 (98)00274-1

Gartner Survey Highlights Consumer Fatigue with Social Media. (2011). Retrieved from https://www. gartner.com/newsroom/id/1766814

Givas, N. (2020, March 20). WHO haunted by old tweet saying China found no human transmission of coronavirus. Retrieved from https://nypost.com/2020/ 03/20/who-haunted-by-old-tweet-saying-chinafound-no-human-transmission-of-coronavirus/

Haddon, C., Hogarth, R., Nice, A., \& Marshall, J. (2020). Coronavirus Act 2020. Retrieved from https:// www.instituteforgovernment.org.uk/explainers/ coronavirus-act

Hao, K. (2020, April 17). Machine learning could check if you're social distancing properly at work. Retrieved from https://www.technologyreview.com/2020/ 04/17/1000092/ai-machine-learning-watches-socialdistancing-at-work/

Hawkley, L. C., \& Capitanio, J. P. (2015). Perceived social isolation, evolutionary fitness and health outcomes: a lifespan approach. Philosophical Transactions of the Royal Society B: Biological Sciences, 370 (1669), 20140114. doi: 10.1098/rstb.2014.0114

Holden, M. (2020, April 1). UK police chided for overzealous response to coronavirus lockdown. Retrieved from https://uk.reuters.com/article/uk-health-coronavirus-britain-police/uk-police-criticised-for-overzealous-lockdown-response-idUKKBN21IOOC

Hunt, E. (2015, November 03). Essena O'Neill quits Instagram claiming social media 'is not real life'. Retrieved from https://www.theguardian.com/me$\mathrm{dia} / 2015 / \mathrm{nov} / 03 /$ instagram-star-essena-oneillquits-2d-life-to-reveal-true-story-behind-images

Kaste, M. (2016, April 8). Why The FBI Director Puts Tape Over His Webcam. Retrieved from https://www. npr.org/sections/thetwo-way/2016/04/08/ 473548674/why-the-fbi-director-puts-tape-over-hiswebcam

Kelley, E. (2019). Scientists call for Protection from Non-ionizing Electromagnetic Field Exposure. Retrieved from https://emfscientist.org/index.php/emfscientist-appeal

Krasnova, H., Spiekermann, S., Koroleva, K., \& Hildebrand, T. (2010). Online social networks: Why we disclose. Journal of Information Technology, 25(2), 109-125. doi:10.1057/jit.2010.6

Kraut, R., Kiesler, S., Boneva, B., Cummings, J., Helgeson, V., \& Crawford, A. (2002, December 17). SPSSI Journals. Retrieved from https://spssi.onlinelibrary. wiley.com/doi/abs/10.1111/1540-4560.00248

Lee, S. J. (2009). Online Communication and Adolescent Social Ties: Who benefits more from Internet use? Journal of Computer-Mediated Communication, 14(3), 509-531. doi: 10.1111/j.1083-6101.2009. 01451.x

Lee, P. S. N., Leung, L., Lo, V., Xiong, C., \& Wu, T. (2010). Internet Communication Versus Face-to-face Interaction in Quality of Life. Social Indicators Research, 100(3), 375-389. doi: 10.1007/s11205-0109618-3

Lee, A. R., Son, S.-M., \& Kim, K. K. (2016). Information and communication technology overload and social networking service fatigue: A stress perspective. Computers in Human Behavior, 55, 51-61. doi: 10.1016/ j.chb.2015.08.011

Leitschuh, J. (2019, September 25). Zoom Zero Day: 4 Million Webcams \& maybe an RCE? Just get them to visit your website! Retrieved from https://medium. com/bugbountywriteup/zoom-zero-day-4-millionwebcams-maybe-an-rce-just-get-them-to-visit-yourwebsite-ac75c83f4ef5

Martínez-Córcoles, M., Teichmann, M., \& Murdvee, M. (2017). Assessing technophobia and technophilia: Development and validation of a questionnaire. Technology in Society, 51, 183-188. doi: 10.1016/ j.techsoc.2017.09.007

Maj, M., Akiskal, H. S., López-Ibor, J. J. J., \& Okasha, A. (2004). Phobias. Hoboken, NJ: John Wiley \& Sons.

Munshi, S., Loh, M. K., Ferrara, N., Dejoseph, M. R., Ritger, A., Padival, M., ... Rosenkranz, J. A. (2020). 
Repeated stress induces a pro-inflammatory state, increases amygdala neuronal and microglial activation, and causes anxiety in adult male rats. Brain, Behavior, and Immunity, 84, 180-199. doi: 10.1016/j. bbi.2019.11.023

O’Neill, B. (2020). Derbyshire police should leave those dog walkers alone. Retrieved from https://www. spectator.co.uk/article/derbyshire-police-shouldleave-those-dog-walkers-alone

Osiceanu, M.-E. (2015). Psychological Implications of Modern Technologies: "Technophobia" versus "Technophilia." Procedia - Social and Behavioral Sciences, 180, 1137-1144. doi: 10.1016/j.sbspro.2015.02.229

Pénard, T., \& Poussing, N. (2010). Internet Use and Social Capital: The Strength of Virtual Ties. Journal of Economic Issues, 44(3), 569-595. doi: 10.2753/ jei0021-3624440301

Russell, C. L. (2018). 5 G wireless telecommunications expansion: Public health and environmental implications. Environmental Research, 165, 484-495. doi: 10.1016/j.envres.2018.01.016

Scissors, L., Burke, M., \& Wengrovitz, S. (2016). What$\mathrm{s}$ in a Like? Attitudes and behaviors around receiving
Likes on Facebook. Proceedings of the 19th ACM Conference on Computer-Supported Cooperative Work \& Social Computing - CSCW 16. doi:10.1145/ 2818048.2820066

Tarafdar, M., Tu, Q., Ragu-Nathan, B. S. \& Ragu-Nathan, T. S. (2007). The impact of technostress on role stress and productivity. Journal of Management Information Systems, 24(1), 301-328. doi: https://doi. org/10.2753/MIS0742-1222240109

Valkenburg, P., \& Peter, J. (2005). Adolescents' online communication and their closeness to friends. Paper presented at the International Communication Association, New York.

Wellmann, B., Haase, A. Q., Witte, J., \& Hampton K. (2001). Does the Internet Increase, Decrease, or Supplement Social Capital?: Social Networks, Participation, and Community Commitment. American Behavioral Scientist, 45(3), 436-455.

Zhou, C., \& Xiao, B. (2020, January 2). 'We are basically living naked': The complicated truth about China's Social Credit System. Retrieved from https:// www.abc.net.au/news/2020-01-02/china-social-credit-system-operational-by-2020/11764740 